\title{
Queerowanie (nie)tożsamości lesbijskiej na podstawie opowiadań Agnieszki Kłos
}

Ewa Dec

badaczka niezależna

\begin{abstract}
[Artkuł ukazał się wcześniej na łamach InterAliów w sekcji artykuły bieżące, tutaj.] Artykut jest próba reinterpretacji znanych i nośnych teorii powiązanych z krytyka feministyczna i psychoanaliza na podstawie opowiadań zawierajacych wątki lesbijskie. Odczytanie wybranych tekstów literackich ma charakter queerowy, jest krytyczne nastawione do normatywnych tożsamości i próbuje ukonstytuować lesbijska (nie)tożsamość. Jest to próba odnalezienia queerowego języka lesbijek.
\end{abstract}

Słowa kluczowe: Agnieszka Kłos, tożsamość lesbijska, płeć kulturowa, psychoanaliza

\section{Wstęp}

Analizując polskie teksty mówiące o miłości między kobietami, szczególną uwagę poświęciłam Agnieszce Kłos. W obrębie moich zainteresowań znalazły się kategorie tożsamości, a przede wszystkim skupiłam się na próbie ich budowania i (de)konstruowania. Czytając teksty polskich autorek piszących o wątkach lesbijskich, zauważyłam zwrot ku mitologizacji relacji między kobietami, przypisywanie im sprawczej mocy konstruowania własnej tożsamości w opozycji do heteronormy, wytwarzanie swoistej lesbijskiej niszy - bezpiecznego miejsca, sprzyjającego rozwojowi własnego języka i nieuwikłanej w normy kulturowe tożsamości. Z perspektywy niszczenia heteronormatywnych wzorców i klisz opisywane relacje lesbijskie są bez wątpienia burzycielskie. Pozwalają na swobodne wytwarzanie własnych narracji i tożsamości. Jednak zbiór opowiadań Agnieszki Kłos Całkowity koszt wszystkiego, różni się od reszty tekstów z wątkami lesbijskimi. Mam tu oczywiście na myśli interesujące mnie kategorie budowania tożsamości i ich (de)konstrukcje. Nie tylko kwestie tożsamościowe pozostają w nim sproblematyzowane, dzieje się tak również z relacjami pomiędzy kobietami, relacje te nie stanowią już bezpiecznej, przyjaznej przestrzeni i mitologicznej niszy. Wręcz przeciwnie - są one zalążkiem napięć, niepewności, a więc krytycznie odnoszą się do wszelkich mitologizacji. Narracje prowadzone przez Kłos dalece odbiegają od innych, istniejących na gruncie polskim tekstów o tematyce lesbijskiej. Catkowity koszt wszystkiego zawiera queerowe wątki, a tożsamość bohaterki jest niejednoznaczna. Świadczy o tym płynna kategoria płci i ról, a jedyną stałą, jaką można odnaleźć w tekstach, jest pożądanie skierowane w kierunku kobiet. Natomiast obiekt, który pożąda, pozostaje tożsamościowo nieokreślony. W zależności od opowiadania przybiera on mniej lub bardziej stereotypowe cechy płci formułowane przez kulturę. Zdarza się również tak, że podmiot wychodzi całkowicie poza płeć biologiczną, co koresponduje z nośną dziś, sformułowana przez Butler, koncepcją performatywności płci. W tym też kontekście warto Kłos odczytywać. Jednak w jej przypadku należy przyjrzeć się nie tylko dekonstrukcjom tożsamości bliskim myśli Butler, warto dodać również odczytanie psychoanalityczne. Mam tu na myśli pewne modyfikacje teorii znanych psychoanalityków (a w szczególności Freuda nazywającego w swych tekstach kobiecą seksualność mianem czarnego kontynentu psychoanalizy (Freud 1995: 149) po części obalane, a po części przeformułowywane przez psychoanalityczki, próbujące stworzyć bardziej autonomiiczną koncepcję kobiecej seksualności. W ten właśnie sposób, łącząc polemikę z myślą Freudowską 
(którą postaram się rozwinąć i zmodyfikować) z nieufnym podejściem do esencjalistycznych tożsamości (postulowanych również przez pewną grupę teoretyczek feministycznych) oraz queerującymi postulatami Butler, postaram się odczytywać opowiadania Kłos.

\section{Krytyczne przyglądanie się Freudowi}

Aby najpełniej ukazać płynność tożsamości i zupełne obalenie struktur płciowych u Kłos, warto zacząć od opowiadania Kutas. Na jego gruncie można bowiem dokonać dekonstrukcyjnych odczytań wymierzonych nie tylko w dyskurs esencjalistyczny, ale również w psychoanalizę Freuda, będącą co prawda impulsem do powstania narracji o seksualności w jej współczesnym kształcie, ale wciąż traktującą kobiece pożądanie jako wtórne i uwikłane w struktury władzy fallicznej.

Bohaterkę opowiadania zastajemy w łóżku tuż po przebudzeniu. Jest ona zdziwiona faktem, że obok niej leży nieznajoma kobieta. Bohaterka popada w jeszcze większe zdziwienie odkrywając, że obudziła się, mając penisa:

[...] dziewczyna spała twardziej niż ja i wcale nie chciała się obudzić. Odchyliłam kołdrę, żeby zobaczyć, jakie ma nogi i zdębiałam. Miałam na sobie białe bokserki, a między nogami kutasa. O kurcze, pomyślałam, tym razem przegięłam. Kutas leżał bokiem w spodenkach. Miał pod sobą jądra i wyglądał jakby płynął na dmuchanym materacu. Miałam owłosione nogi, mimo że goliłam je dwa dni temu. I pazury zamiast paznokci u nóg. (Kłos 2007: 155)

Skojarzenie tego fragmentu z koncepcjami Butler jest oczywiste. Penis i inne męskie cechy pojawiające się u kobiety, można odczytać jako metaforyczne artefakty potwierdzające teorię mówiącą o performatywnych aktach płci. Należy pamiętać, że Butler zrewolucjonizowała myślenie o kategorii gender. Stojąc po stronie konstruktywizmu, poszła o krok dalej niż inni jego zwolennicy. Według niej, to kultura wytwarza biologiczne upłciowienie poprzez akty performatywne. W tym rozumieniu, płeć biologiczna nie jest fundamentalną jednostką odniesienia, jest za to w pewnym sensie wtórna, wytwarzana przez performatywne akty płci już od momentu narodzenia. Pojawienie się penisa może więc być wyrazem metaforycznego wyjścia poza kulturowe kształtowanie płci i tożsamości. Ukazuje ono płynność tych kategorii, szczególnie w związku lesbijskim, gdzie wyjście poza ustanawianą przez kulturę "męskość" i "kobiecość" jest znaczenie łatwiejsze. W tym kontekście, odejście przez bohaterkę od narzuconych ról płciowych i odrzucenie heteronormy jest wyrazem wyjścia poza binarnie rozumianą płeć. Jak pisała Butler, jeśli płeć kulturowa jest wytwarzana przez stałe podtrzymywanie jej cech, wtedy pojęcia esencjalnej, biologicznej płci są częścią strategii, która ma za zadanie ukryć, że kulturowa płeć ma charakter performatywny, a więc można by pomnażać liczbę jej konfiguracji, wychodząc poza ustalone ramy męskiej dominacji i obowiązkowej heteroseksualności (Butler 2008: 254). Bohaterka Kłos przeciwstawia się tradycyjnym kulturowo rolom kobiet, podejmuje aktywność oraz wchodzi w relacje lesbijskie. Jest to poniekąd obalenie esencjalistyczych struktur płci, znanych, narzucanych kulturowo kategorii i cech tożsamościowych (płciowych) i zastąpienie ich swobodną kreacją własnej tożsamości. Co znajduje odzwierciedlenie w pojawieniu się u kobiety penisa, będącego metaforyczną oznaką queerowej tożsamości, wyjścia poza ustanowione kulturowo ramy. 
Odczytanie to można poszerzyć o interpretację psychoanalityczną. Mam tu na myśli wspomniane feministyczne przeformułowanie teorii Freuda. Skojarzenia z postulowanymi przez tego psychoanalityka koncepcjami zazdrości o penisa są oczywiste. Sama bohaterka wspomina wydarzenie tymi słowami:

Mówią, że to nieprawda, że nie kutas rządzi światem, ale są jeszcze inne rzeczy. Nie wierzę. Kiedyś wierzyłam. Mogłam o świecie rozprawiać całymi dniami z przyjaciółmi i nie sugerować się jakimś kawałkiem skóry. Nie teraz. Od czasu tamtego ranka już wiem, kto panuje nad tym światem. (Kłos 2007: 114)

Aby w pełni zrozumieć tok rozpoczętych rozważań, należy przypomnieć sobie pozycję, z jakiej Freud obserwował i opisywał kobiecą seksualność. Psychoanalityk postrzegał libido jako artefakt wyłącznie męski, niezależnie od tego, u której z płci miałoby się ono przejawiać. Dlatego, choć twierdził, iż dziewczynki w równym stopniu co chłopcy przejawiają aktywność popędów częściowych oraz aktywność falliczną (Freud 2005: 136), był przekonany, że aby ukonstytuowała się kobiecość, popędy te muszą zostać wyparte. Stąd łatwo o wniosek, że dla Freuda warunkiem zaistnienia kobiecości jest przemiana aktywności w bierność. W ten sposób, popędy odpowiedzialne za skłonność do przywłaszczania sobie jednostek i rzeczy oraz dominacji, zostaną zastąpione przez potrzebę bycia posiadaną, obnażaną i skromną. Miało to skutkować pojawieniem się różnicy płciowej i zaistnieniem cech kobiecości i męskości, co następowało we wczesnym dzieciństwie (Irigaray 2010: 31). Bez wątpienia teorie te są z gruntu maskulinistyczne i niemiarodajne ze względu na obsadzanie, obserwowanie i opisywanie kobiecości zawsze wobec męskości.

Wobec przyjęcia takiej tezy, penis z którym budzi się główna bohaterka jest fantazmatem libido. Zjednej strony spełnia on rolę artefaktu symbolizującego aktywność, rozbudzoną seksualność i władzę, z drugiej - pamiętając o queerowej teorii Butler, nie można odczytywać go w ramach przynależności do danej płci. W tym kontekście słowa bohaterki: "Mówią, że to nieprawda, że nie kutas rządzi światem, ale są jeszcze inne rzeczy. Nie wierzę. Kiedyś wierzyłam [...] Nie teraz. Od czasu tamtego ranka już wiem, kto panuje nad tym światem" (Kłos 2007: 114) ujawniają nie tyle przyjęty przez Freuda i całą kulturę fallocentryzm, co posłużenie się symbolicznym i typowym dla tego dyskursu symbolem. W tym przypadku, to nie męskość zostaje ukazana jako źródło siły i sprawczej energii. Dzieje się wręcz przeciwnie. Symbol falliczny oraz wspomniana kategoria, zostaje zdekonstruowana i przeformułowana. Bohaterka kulturowo pozostaje kobietą, kutas jest tylko artefaktem, mającym przybliżyć kategorię władzy. Symbol ten ulega przewartościowaniu i przekonstruowaniu na kilku płaszczyznach, z których najjaskrawiej odznacza się przejęcie przez kobietę zawłaszczonej przez męskość władzy oraz aktywności seksualnej, uznawanej przez Freuda za cechę męską. W tym odczytaniu duże znaczenie odgrywa odrzucenie wzorca heteroseksualnego, na rzecz pożądania kierowanego ku innej kobiecie. Kobieca aktywność i relacja lesbijska rozbija patriarchalny porządek, przeciwstawiając się kulturowo narzuconej bierności, odsłaniając niemiarodajność i płynność kategorii przyjmowanych przez myśl Freudowską. Symboliczny penis nie jest więc już przynależny jedynie mężczyźnie, pozostaje natomiast atrybutem władzy i aktywności seksualnej, należne i dostępnej każdemu podmiotowi: 
Dziewczyna była taka leniwa w tym wszystkim, a ja nie. Przeciwnie, czułam się jak zając. W ogóle od razu wiedziałam co robić [...] Nie ja kierowałam tę akcją i nie ja decydowałam w tej chwili, bo komendę przejął ten kutas. Tępy, umięśniony, głupi typ [...] nic już nie robiłam do końca dnia. On sam to robił. [...] Nie czułam się zmęczona, bo tylko kutas dyrygował. W sumie mogłabym nawet nic nie robić, bo on był bardzo samodzielny. (Kłos 2007: 16-18)

Takie odczytanie opowiadania Kłos prowadzi do zdekonstruowania kulturowego przekonania o cechach kobiecych i męskich, ukazuje sztuczność tych kategorii, a myśl Butlerowska dopełnia tezę o ich nieprzystawalności i ukazuje je jako płynne, przenikające się i niemożliwe do strukturalnego opisania.

W kontekście przeciwstawienia myśli Freudowskiej postulatom późniejszych psychoanalityczek oraz queerowej teorii Butler, na podstawie opowiadania Kutas, ciekawie wydaje się rysować kwestia zazdrości o penisa. Tę kontrowersyjną teorię reinterpretowała Luce Irigaray, upatrując we Freudowskich postulatach ignorancji dla kobiecej seksualności oraz przypisywaniu jej istnienia wyłącznie w połączeniu z męskim fallicznym pragnieniem. Według Freuda, kobieta skazana jest na brak, który wiąże się z nieposiadaniem fallusa. Miałoby to nieść za sobą skutki odciskające piętno na całym jej życiu, poczynając od sfery seksualnej, na relacjach społecznych kończąc. Ów brak miałby rodzić wspomnianą zazdrość o penisa, a całe późniejsze życie kobiety opierać się na próbie przywłaszczenia sobie za wszelką cenę tego cenionego przez kulturę atrybutu. Próby odnalezienia pełni i wyzbycia się zazdrości przybierać miały różnorakie formy, takie jak obdarzanie uległą miłością ojcamęża (mogącego fallusa ofiarować) czy chęć posiadania dziecka, najlepiej chłopca, mającego wynagrodzić brak, a także wtajemniczyć kobietę w posiadanie męskiego organu. Wszelkie Pragnienia kobiet są więc podporządkowane potrzebie wejścia w posiadanie odpowiednika fallusa (Irigaray 2010: 19). Irigaray, podobnie jak większość badaczy i badaczek, krytykuje Freudowskie koncepcje, zarzucając im definiowanie kobiecej seksualności wyłącznie w stosunku do męskiej. To, co kobiece, opisywane jest przez Freuda jako zanik i niedostatek męskości, przenicowana płeć, będąca jedynie odwrotnością reprezentującej wszelkie wartości płci męskiej (Irigaray 2010: 58). Według psychoanalityka, kiedy dziewczynka we wczesnym dzieciństwie odkrywa, że nie posiada penisa, zmuszona jest pogodzić się z tym jako z faktem dokonanym i nieodwracalnym. Irigaray pisze: „uznaje ona, a raczej powinna uznać, że w porównaniu z chłopcem pozbawiona jest płci, a przynajmniej, że to, co brała za cenny dotąd organ płciowy, nie jest niczym więcej aniżeli uciętym penisem" (Irigaray 2010: 33). Stąd Freudowskie przekonanie o zazdrości o penisa. W tym rozumieniu, kobieta miałaby być tylko narzędziem zaspokajającym męską potrzebę władzy, odnajdując w tym przyjemność, co miałoby związek ze zbliżeniem się do nienależącego do niej artefaktu, niemożliwą próbą przywłaszczenia go sobie.

By w pełni zarysować polemiczny z Freudowską teorią wydźwięk opowiadania, warto przyjrzeć się się temu, jak klasyczna psychoanaliza postrzegała kobiecą nieheteroseksualność. Zarówno Freud jak i Lacan rozpatrywali ją w ramach męskiego dyskursu fallocentrycznego. Dla Freuda lesbijskość była więc niczym więcej, jak skutkiem kompleksu męskości, zaistniałego przez domniemaną zazdrość o penisa. Skierowanie pożądania w stronę innych kobiet miało być spowodowane narcystycznym zranieniem zadanym przez ojca, co skłaniało dziewczynkę do cofnięcia się w etap dziecięcej męs- 
kości. W przyszłości miała więc wybierać obiekty miłości przynależne mężczyźnie i w relacji z wybranym obiektem przyjmować odtąd role męską (Freud 1995: 148-149). Nie mniej fallocentrycznie postrzega lesbijskość Lacan. Łączy ją w pewnym stopniu z oziębłością, z zaprzeczeniem seksualności. Podobnie jak Freud, doszukuje się jej istoty w heteroseksualnym rozczarowaniu.

Twierdzenia obu psychoanalityków na współczesnym gruncie brzmią nieco anachroniczne. Nieprzystawalność ta wiąże się z brakiem rozpatrywania kwestii seksualności z perspektywy kulturowej. Na tym też polu Freuda i Lacana skrytykowały współczesne badaczki, proponując reinterpretacje ich teorii. Polemikę z Lacanem podjęła Butler, zarzucając mu obserwację z męskiego i heteroseksual.nego punktu widzenia, z którego lesbijska seksualność będzie postrzegana jako „odrzucenie seksualności jako takiej", a podmiot mówiący ukonstytuowany jako heteroseksualny mężczyzna zawsze spotka się z odmową (Butler 2008: 121). W podobnym tonie z Freudem polemizuje Irigaray, twierdząc, że nie bada on kulturowo, że pomija historyczne i społeczne czynniki mające wpływ na kobiecą egzystencję, tym samym skazując kobiety na podporządkowanie dominującemu dyskursowi ojca, a co za tym idzie, stłumienie ich żądań i protestów (Irigaray 2010: 59).

Pamiętając o takich odczytaniach kanonu klasycznej psychoanalizy, nietrudno spojrzeć na opowiadania Kłos jako na polemikę z przyjmowaną przez psychoanalityków optyką, wykluczająca perspektywę historyczną i kulturową. W tym kontekście cały dyskurs związany z zazdrością o penisa dekonstruuje się, a przez jego reinterpretacje dochodzą do głosu teorie oddalone od fallocentryzmu.

Bohaterka Kłos nie jest ofiarą zazdrości o penisa, jej seksualna aktywność i siła nie wynikają z zaspokajania kompleksu, są one raczej wynikiem płynności zachodzącej między kategoriami płci, postrzeganej w tym kontekście jako coś, co ukonstytuowało się na płaszczyźnie kulturowej (przez relacje lesbijską z bierną partnerką chociażby). Nie chodzi w tym momencie o stałą i twardą strukturalnie płeć, ale o płeć konstruującą się na przestrzeni kultury i danego kontekstu sytuacyjnego. Płeć bohaterki nie jest naddana, lecz ciągle stwarza się, nie można więc używać w stosunku do narracji Kłos narzędzi postulujących jakiekolwiek stałe kategorie płciowe i tożsamościowe. Nie sposób wpisać jej nawet w reinterpretacyjne dyskursy kontynuatorów Freuda, takie jak przeformułowanie teorii zazdrości o penisa, autorstwa Karen Horney, zakładające nie biologiczne ukonstytuowanie płci, ale zazdrość wynikającą z pozbawienia kobiet przywilejów (zwłaszcza seksualnych) zarezerwowanych dla mężczyzn. Bohaterka Kłos bowiem w pełni realizuje się seksualnie, nie jest pozbawiona mocy (kulturowo zarezerwowanej dla mężczyzn), sfera ta nie jest tu źródłem problemów. Kobieta nie napotyka na bariery wynikające z posiadanej płci. Można by stwierdzić, że jej płeć jest queerowa, co symbolizuje pojawiający się po przebudzeniu kutas. Nie jest on jednak w żaden sposób związany z teoriami klasyków psychoanalizy, zakładających jakikolwiek kobiecy brak na tle seksualnym czy społecznym. Należy go raczej odczytywać jako znak płci konstruowanej kulturowo, wyjścia poza ustalone, tradycyjne ramy kobiecości. Kutas jest więc nie tylko atrybutem płci queerowej, budowanej w zależności od sytuacji i kontekstu, ale też wyrazem polemiki z klasycznymi teoriami psychoanalitycznymi, zakładającymi stałość kategorii płci. Kłos zdaje się więc nie tylko całkowicie queerować tożsamości, ale też dekonstruować kanon tradycyjnej psychoanalizy. 


\section{Queerowa (nie)tożsamość - dialog z dyskursem teoretycznym}

Opowiadania Kłos można odczytywać nie tylko jako reinterpretacje kanonu psychoanalizy. Specyficzna oniryczna konwencja, brak wyraźnej granicy dzielącej kobiecość od męskości i relacje lesbijskie towarzyszące bohaterce zbioru, pozwalają na reinterpretacje wielu innych koncepcji znanych teoretyków. Podobnie jak u innych polskich autorek, teksty Kłos dekonstruują binarne opozycje płci i tożsamości, ale w jej przypadku kategorie te są zupełnie płynne, konstruowane na potrzebę danej chwili, zmieniające się wraz ze zmianą sytuacji zewnętrznych oddziałujących na bohaterki. Można to zaobserwować nie tylko na podstawie częstych u tej autorki motywów żonglowania kategoriami płci, stereotypami kulturowymi oraz zupełnym rozmyciem twardych struktur tożsamości. Warto spojrzeć na opowiadania Kłos jako na polemikę ze znanymi teoretykami i psychoanalizą (jak w przypadku opowiadania Kutas). Co prawa, w ten sposób można też odczytywać teksty innych autorek piszących o relacjach lesbijskich, ale u Kłos zabieg ten zdaje się skutkować najciekawszymi interpretacjami. Można posłużyć się tu tezami feministek drugiej fali o podejściu esencjalistycznym, by odczytać wybrane teksty polemicznie. Warto dodatkowo zwrócić uwagę na koncepcję rozwijaną przez Irigaray, zaczerpniętą z myśli Levi-Straussa (1949), dotyczącą kultury opartej na wymianie kobiet. W jej tekstach można bowiem doszukać się zbieżności i nawiązań do tej teorii, której obsadzenie w jednej linii z zabiegiem queerowania płci i tożsamości oraz obserwacja z płaszczyzny związku lesbijskiego, powodują wywrotowość pierwotnego jej sensu i dekonstruują patriarchalną strukturę społeczeństwa, opartą na binarnych, pozbawionych płynności rozróżnieniach cech płciowych.

Relacje między kobietami opisywane w zbiorze Całkowity koszt wszystkiego wymykają się projektowi rzeczywistości zawartemu w lesbijskim kontinuum Adrienne Rich. Związki i romanse głównej bohaterki nie są wpisane w stereotypowy idealistyczny obraz miłości między kobietami. Można za to doszukać się w nich pewnego odzwierciedlenia wspomnianej koncepcji wymiany kobiet, rozwijanej przez Irigaray. Większość opisywanych w zbiorze relacji, polega głównie na chęci zdobywania i posiadania, można zatem odczytać je jako postulowaną przez wielu teoretyków kategorie wymiany kobiet jako towaru. Wydaje się to rozsądne, biorąc pod uwagę koncepcję Sedgwick, mówiącą o pragnieniu homospołecznym, bowiem bohaterka niejednokrotnie wchodzi również w role genderowo męską, uczestnicząc w wymianie kobiet, dekonstruując w pewnym stopniu założenia męskiego pragnienia homospołecznego i opartej na nim władzy nad kobietami. Owo zagarnięcie stereotypowo męskich przestrzeni opierających się na zdobywaniu i wymianie kobiet, to element stale powracający w tekstach Kłos.

Idealnym tego przykładem (a zarazem wprowadzeniem do ukazania dekonstrukcji wspomnianych koncepcji) jest opowiadanie To mi wystaje ze spodni, Aido. Tekst mówi o nieszczęśliwie ulokowanych uczuciach bohaterki i bezskutecznej próbie wyzbycia się ich poprzez relacje z inną kobietą:

Byłam pewna, że te noce to tylko kilka warstw brudnej pościeli, prześcieradeł, bo wtedy kochałam się w e. Stałam na ulicy i tak właśnie myślałam: oddać to do prania, pozbyć się nocy i bandaży. [...] Wpadałam pod podłogę i zatapiałam się w e po szyję. To się nazywa całkowite zadłużenie. W każdym autobusie i tramwaju wylewałam swoja zawartość na pasażerów. Zarażałam wszystkich. [...] Tak, panowie, 
oto kolejna stacja pożądania. A e bawiła tymczasem na wyspie Gender, zakuta swoim zwyczajem w kilka warstw skorup, pośrodku zwartego stada starych kobiet. (Kłos 2007: 8-9)

Ten melancholijny opis nieszczęśliwego uczucia ulokowanego w kobiecie i bezskutecznej próby wyzbycia się go wpisuje się w stereotypową retorykę tekstów mówiących o miłości lesbijskiej. Można z niego odczytać figury miłosne, takie jak nieobecność czy tęsknota, typowe dla podmiotu zakochanego, opisane przez Barthesa we Fragmentach dyskursu miłosnego. Z melancholijnym nastrojem kontrastuje jednak opis prób odsunięcia od siebie nieszczęśliwego uczucia, podejmowanych przez bohaterkę oraz nocnych eskapad na które zapuszczała się wraz z mężczyznami:

To nie jest historia skończona. Kiedy myślę o tamtej nocy wykutej w jednym odłamku śniegu, kiedy marcinek, marek i ja łaziliśmy przez jedną porę karmienia, szukając jakiegoś wejścia do teatru, chuj wie po co. I był śnieg. Bardzo zimne powietrze. Zaułek krakowski, który mi przyniósł ten bardzo dziwny jazzsen. No i były te knajpy. Ja wtedy postanowiłam się zapić. Nosiłam męskie gacie i wielkiego chuja pełnego pozy i żądzy. Było we mnie po połowie żądzy i smutku. (Kłos 2007: 8)

Można tu znaleźć bezpośrednie nawiązania falliczne, podobnie jak w tytule opowiadania. Bohaterka pomimo fatalnej miłości do kobiety, zapuszcza się w nocy do miasta, odwiedza puby, pije i brata z mężczyznami. Te nocne wyjścia i wspólne picie alkoholu mają poniekąd znaczenie rytualne. W tym przypadku kobieta zostaje włączona w niedostępne innym kobietom wtajemniczenie. Dzieląc doświadczenia bliskie grupie mężczyzn, związane z chęcią zdobycia kobiety, wchodzi w ich środowisko, pełniąc rolę genderowo męską. Tym samym, wchodzi w mechanizm męskiego Pragnienia homospołecznego. Bohaterce pozwala na to dzielenie kulturowo zarezerwowanego dla mężczyzn prymatu władzy, który nawet w sytuacji melancholijnej tęsknoty za obiektem uczuć, opiera się na wymianie kobiet między mężczyznami. Falliczne nawiązania nie są tu przypadkowe: "nosiłam męskie gacie i wielkiego chuja pełnego pozy i żądzy. Było we mnie po połowie żądzy i smutku" (Kłos 2007: 8), mają znaczenie odsłaniające kulturową pozycje bohaterki podobną do tej, którą zajmowała w opowiadaniu Kutas. Chodzi oczywiście o rezygnacje z bierności, wejście w role stereotypowo męskie, o falliczność. Ciekawe w tym kontekście wydają się być relacje bohaterki z mężczyznami. Jak już wspomniałam, korespondują one z teoriami mówiącymi o pragnieniu homospołecznym, a co za tym idzie o ekonomii opartej na wymianie kobiet. W innych, zawierających wątki lesbijskie opowiadaniach Kłos, również występują podobne motywy. W tekście Pomniejszenie czytamy:

Myślałam o tobie kiedy chlałam z chłopcami w barze. Właściwie nie chlałam, tylko piłam dla towarzystwa alkohol w brudnym, zatłoczonym barze, który właśnie wyremontowali. Był piątek wieczór. Wszyscy się gdzieś wybierali i moi chłopcy również. Więc z nimi poszłam, żeby nie siedzieć w domu i przypadkiem nie myśleć bez przerwy o tobie. Nie wyszło mi jednak na dobre takie niemyślenie w domu, tylko przy obcych. (Kłos 2007: 8) 
Podobnie jak w poprzednim opowiadaniu, mamy tu do czynienia z niespełnionym uczuciem do kobiety. Podobnie również emocjom tym towarzyszy sytuacja wejścia kobiety w męską społeczność. Ma ona znamiona postulowanego przez Sedgwick męskiego pragnienia homospołecznego. Jedynym szczegółem odróżniającym sceny obserwowane w opowiadaniach od modelowej relacji homospołecznej jest płeć bohaterki. Oprócz tego jej relacje z mężczyznami naznaczone są tradycyjnymi dla pragnienia homospołecznego cechami. Pojawia się w nich typowa dla koncepcji Sedgwick chęć bliskości, poczucia solidarności grupowej, z jednoczesną silną potrzebą uzewnętrznianiem swojej męskości, odgrywaniem maczoidalnych póz, po to tylko, by nie zostać posądzonym o bycie homoseksualistą. Nasza bohaterka również uczestniczy w tych praktykach. Jej płeć jest niejednoznaczna, $z$ jednej strony jest kobietą pożądającą innych kobiet, cierpiąca z powodu nieodwzajemnionego uczucia, z drugiej, staje się jednym z mężczyzn, zostaje wtajemniczona, funkcjonując w tej grupie genderowo jako mężczyzna, udowadniając swoją fallicznosć i przybierając stereotypowo męskie pozy. Dzieje się tak najpewniej dlatego, że bohaterka kieruje swe pożądanie ku innym kobietom. Tym samym wchodzi w dostępną tylko dla mężczyzn wspólnotę, której celem i przywilejem jest wzajemna wymiana kobiet. Taką tendencję można odczytać w większości opowiadań Kłos, którym daleko do postulowanych przez niektóre teoretyczki feministyczne idealistycznych obrazów bliskości i jedni między kobietami. Motyw postrzegania kobiet przez główną bohaterkę jako cennych zdobyczy, powtarza się niezmiernie często:

Lubię sobie popatrzeć na dziewczyny, więc gdziekolwiek się pojawiam, zawsze to robię. Nie mam pojęcia, czy jest to bardzo podejrzane albo zakazane i czy tak samo zachowują się inne babki. Sadzę, że niektóre robią to bezwiednie. Widziałam nawet taką sytuację obgapiania się podczas tego wieczoru w barze. Konkretnie podczas występu tancerek. Raz patrzyłam na te tancerki, raz na niektóre dziewczyny, które nie mogły odkleić od nich wzroku. Większa frajdę mi sprawiało gapienie się na te zapatrzone dziewczyny, bo miały zupełnie niemądre, nieobecne miny. (Kłos 2007: 10-11)

Mamy tu do czynienia ze zmianą symbolicznych ról. Bohaterka wychodzi z roli biernej i obserwowanej, kulturowo zarezerwowanej dla kobiet, przejmuje natomiast czynność obserwowania, co w patriarchalna kultura postrzega jako rolę typowo męską. W tym kontekście warto pamiętać o wspominanej teorii Irigaray, związanej z wymianą kobiet między mężczyznami. Bohaterka Kłos, zmieniając genderową rolę, a tym samym wchodząc w relacje homospołeczne z mężczyznami, zostaje dopuszczona przez nich do rynku kobiet, polegającego na wymianie, mającego na celu umożliwienie mężczyznom zacieśniania relacji w swoim gronie. Jak pisze Irigaray, w tej rzeczywistości kobieta zyskuje wartość o tyle, o ile stanowi cenę w relacjach między mężczyznami. Użytkowanie i wymiana kobiet podtrzymują męskocentryczny obraz świata i panowanie patriarchatu (Irigaray 2010: 144). Mężczyźni nie dopuszczają kobiet do pozycji partnerskiej w owych wymianach. Nie wymieniają się z nimi, lecz wymieniają się nimi. Kultura wymusza bowiem na kobietach alienację w sferze konsumpcyjnej, a od mężczyzn oczekuje wystrzegania się statusu przedmiotu użytkowego i nieuczestniczenia w obiegu wymian towarowych za żadną cenę (Irigaray 2010: 145). Kłos zdaje się jednak łamać te reguły, w jej relacjach z kobietami można dostrzec pewne wartościowanie ich, przyglądanie się im właśnie z perspektywy wartości użytkowej (co stanowiłoby cenę również w kontekście relacji ze wspomnianymi mężczyznami). 
W opowiadaniu Tylko trochę nieugięta bohaterka spotyka na wyjeździe służbowym dwie kobiety z którymi zostaje zakwaterowana w jednym pokoju. Obie ocenia pod względem fizycznym, nie szczędząc przy tym uwag wskazujących na to, że jej postrzeganie kobiet bliskie jest perspektywie męskocentrycznej, opisanej przez Irigaray: „A potem włączyła telewizor i mogłam się im przyjrzeć. Ta obok miała długie nogi i włosy, którymi bawiła się jak oglądała. A ta druga była brzydka, ale leciała na mnie. To nie był najlepszy wieczór mojego życia" (Kłos 2007: 97). Kobiety oceniane są w sposób typowy dla optyki patriarchalnej. Bohaterka wpisuje się przy tym automatycznie we wspomnianą pozycje symbolicznej władzy, podmiotu wymieniającego się z innymi podmiotami, a kobiety obserwowane przez nią, wchodzą w rolę przedmiotów poddawanych wymianie, których wartość na każdym kroku jest określana i ustanawiana zgodnie z wymaganiami narzucanymi przez kulturę. W dalszej części tekstu, bohaterki wspólnie oceniają inne kobiety. Obie wchodzą w rolę zarezerwowaną przez kulturę dla mężczyzn, choć w tym przypadku cała teoria mówiąca o wymianie towarów ulega dekonstrukcji, gdyż w pierwotnej wersji w pole męskocentrycznych wymian kobiety nie mają dostępu. Zachodzi tu jednak zmiana podyktowana przez ciągle zmieniający się gender bohaterek. Czytamy:

W końcu ta ładna zwinęła się z chłopakiem, a ja zostałam z tą lekko zezowatą na tapczanach. Zobacz, jaka laska, zobacz tę, a ta, jak ci się podoba? Dziewczyna chyba dostała bzika na punkcie tych wszystkich aktorek, które migały po kanałach. Oceniała prezenterki, spikerki z jedynki, dziewczyny z szybkich reklamówek i seriali. W końcu trafiła na program, który opowiadał o życiu kilku modelek, i ucichła z wrażenia. (Kłos 2007: 98)

Tym razem, w rolę oceniającej wchodzi kobieta, będąca wcześniej obiektem oceny innej kobiety. Taka sytuacja nie mogłaby mieć miejsca między mężczyznami, w przestrzeni symbolicznie naznaczonej patriarchalną władzą. Nieheteroseksualność kobiet burzy porządek. Bohaterka zostaje wpuszczona w przestrzeń wymiany kobiet, co w przestrzeni kultury oficjalnej uznawane jest za niemożliwe. W tym kontekście jej płeć staje się niejednoznaczna. Pożądając kobiet, wychodzi z ustanowionej przez patriarchat kulturowej roli kobiety naznaczonej biernością, staje się aktywna i falliczna, co idealnie obrazuje opowiadanie Kutas. Gender bohaterki jest płynny, co pozwala jej na elastyczność, wejście w przestrzenie ustanowione przez kulturę zarówno jako kobiece, jak i męskie. Dzięki temu bohaterka uczestniczy w wymianie kobiet z mężczyznami, stając się genderowo jednym z nich. Trzeba jednak nadmienić, że nie jest to typowa relacja wymiany. Różni się ona między innymi postrzeganiem kobiet - o ile dla mężczyzn kobieta stanowiłaby wartość tylko jako towar umożliwiający relacje z innymi mężczyznami, o tyle dla bohaterki Kłos znaczy ona o wiele więcej. Pomimo odejścia od idyllicznej wizji lesbijskich relacji, naznaczenia potencjalnych partnerek etykieta towaru, bohaterka żywi wobec nich troskę, odchodzi więc od typowego dla męskiej społeczności modelu wymiany. We wspomnianym Pomniejszeniu, bohaterka będąc wtajemniczoną, pełnoprawną członkinią męskiej społeczności, martwi się o kobiety przebywające w barze wraz z innymi mężczyznami, czy te, które spełniają bezpośrednią, przedmiotową rolę wobec mężczyzn: "Tancerki warszawskie machały obrokatowanymi rękoma jak przez szybę. Martwiłam się o nie i o wszystkie dziewczyny z grubymi facetami, które stały pod ścianami. Właściwie mogłabym nad tym zapłakać" (Kłos 2007: 13). Płynność płci kulturowej pozwala kobiecie na wejście jednocześnie na płaszczyzny kilku porządków. Z jednej strony, jest ona dopuszczona do męskiej społeczności, wtajemniczana i trakto- 
wana jak jej pełnoprawny członek. Uczestniczy też w wymianie kobiet, ale zaburzając pewien porządek, załamując hierarchię, wychodząc poza sztywno ustalone normy. Swoja queerową płcią bohaterka wkrada się na każda płaszczyznę, czy to relacji między kobietami, czy zarezerwowanych dla mężczyzn wspólnot. Kobieta wchodzi w nie, dekonstruując i odwracając, tak samo jak dekonstruuje postulowaną przez drugofalowe feministki idee lesbijskiego kontinuum. Jej queerowość i płynna tożsamość pozwalają na wejście w każdy porządek, i na wywrócenie każdego z nich.

Wspomniana wymiana kobiet pomiędzy bohaterką a mężczyznami nie jest do końca harmonijna i modelowa. Co prawda, kobieta zostaje wtajemniczona w męską społeczność, ale jednocześnie część jej tożsamości pozostaje w symbolicznej przestrzeni kobiet. Dlatego nie uczestniczy ona w rytuałach zbliżających ją i pozwalających na członkostwo w męskiej społeczności modelowo. Jako że pozostaje między płciami, jej tożsamość jest płynna, niejednoznaczna i queerowa, uczestnictwo w każdej z kulturowo ustanowionych społeczności sprowadza się do zaburzania ich struktur. Bohaterka nie pasuje do kulturowo ustanowionego obrazu kobiet przez fakt pożądania kierowanego w ich kierunku, a także przez odcięcie się od stereotypów bierności i słabości, odrzucenie „bycia fallusem” na rzecz „posiadania fallusa”. Z pełnego uczestnictwa w społeczności męskiej, wyklucza ją natomiast fakt innego niż członkowie owej społeczności postrzegania kobiet, a także niepełne przystosowanie się do zachodzących między nimi relacji. Bohaterka nie uczestniczy modelowo w wymianie kobiet. Mimo statusu członkini, porywa się ona na pewne odstępstwa, na kradzież kobiet. Jej status nie jest bowiem do końca określony, przez queerową tożsamość pozostaje ona poniekąd intruzem. Wymiana nie zachodzi tu harmonijnie, nie do końca chodzi też o postulowaną przez Sedgwick chęć bratania się z innymi mężczyznami. Bohaterka bowiem, mimo członkostwa w ich społeczności, stawia wyżej relacje z kobietami. W opowiadaniu Obniżka tak opisuje stan zauroczenia: "Na dworze coraz goręcej, niespokojne powietrze, ptaki same umierają na poduszkach mężatek, mężatki same zrzucają majtki dla lesbijek, złodziejek żon" (Kłos 2007: 20). Kobieta zaburza więc w pewien sposób zasady funkcjonowania w męskiej społeczności. Jej niejednoznaczny gender dekonstruuje wszelkie porządki. Podobnie dzieje się w przypadku uczuciowych rozczarowań i niespełnionego pożądania. W tekście Mleczarnia, bohaterka boleśnie doświadcza odejścia kobiety do mężczyzny:

Zamówiłam jej czystą z cytryną, bo zamarzyłam, że jest dziewicą. Cytryna dyndała na bąbelkach jak topielec. Masz moją forsę. Odbiorę, jak wrócę. Muszę teraz stąd wyjść. Dokąd idziesz? Dopiero teraz zobaczyłam tego faceta, który czekał na nią pod ścianą. Kobieta wyrwała swoją rękę i poszła z facetem przed siebie. Miałam plik forsy na resztę wieczoru i puste krzesło naprzeciw. (Kłos 2007: 51)

Będąc członkinią, pozostaje jednocześnie intruzką, złodziejką, doświadcza również bolesnej straty. Bohaterka Kłos wchodzi w struktury nieosiągalne dla jednoznacznych genderowo kobiet. 


\section{„A gdyby »towary« sprzeciwiły się pójściu na »rynek«?" - podsumowanie}

W kontekście moich (re)interpretacji, ciekawa zdaje się być obserwacja poczyniona przez Irigaray. Badaczka krytycznie analizując (w odniesieniu do kobiecej homoseksualności) wspomniane relacja homospołeczne, wymianę kobiet i Freudowskie badania, zadaje pytanie o status lesbijskich relacji po zdekonstruowaniu wymienionych teorii oraz po odrzuceniu męskiej władzy (uznającej je za przydatne jedynie w ramach zaspokajania męskich fantazji). Pyta dosłownie: „A gdyby »towary“ sprzeciwiły się pójściu na »rynek«?" Wbrew wszystkiemu nawiązując między sobą innego rodzaju kontakty i relacje?" (Irigaray 2010: 165). Odpowiedzią jest poczynione przez bohaterkę Kłos obalenie wszelkich możliwych esensjalistycznych teorii, barier między płciami, zniszczenie kanonu teorii i zasad tworzonych przez dyskurs patriarchalny. Uwolnienie podmiotu spod jarzma opresywnej płci kulturowej. Sprzeciwienie się pójściu na rynek oraz nawiązaniu innego typu relacji, a tym samym obalenie męskocentrycznego obrazu nieheteroseksualności kobiet, jako obiektów zaspokajających fantazje mężczyzn jest bowiem możliwe jedynie przez zdekonstruowanie binarnych opozycji płci, tożsamości, twardych kanonicznych teorii i zwrócenie się w kierunku tożsamości queerowej.

\section{Bibliografia}

Baer, Monika. 2004. Najzdrowszy ze sceptycyzmów? Koncepcje ptci i seksualności w antropologii społeczno-kulturowej. W: (red.) Radkiewicz, Małgorzata. Gender. Konteksty. Kraków: Rabid, s. 11-25.

Bauman, Zygmunt. 1995. Ciało i przemoc w obliczu ponowoczesności. Toruń: Wydawnictwo Uniwersytetu Mikołaja Kopernika.

Butler, Judith. 2008. Uwikłani w płeć. Tłum. K. Krasuska. Warszawa: Wydawnictwo Krytyki Politycznej.

Freud, Sigmund. 1995. Wykłady ze wstępu do psychoanalizy. Nowy cykl. Tłum. P. Dybel. Warszawa: Wydawnictwo KR.

Irigaray, Luce. 2010. Ta płeć (jedna) płcia niebędąca. Tłum. S. Królak. Kraków: Wydawnictwo Uniwersytetu Jagiellońskiego.

Kłos, Agnieszka. 2007. Całkowity koszt wszystkiego. Wrocław: Biblioteka Rity Baum.

Kosofsky Sedgwick, Eve. 1990. Epistemology of the Closet. Los Angeles: University of California Press.

- - -. 2005. Męskie pragnienie homospołeczne i polityka seksualności. Tłum. A. Ostolski. W: „Krytyka Polityczna" 9-10, s. 176-186.

Lévi-Strauss, Claude. 1949. Les structures élémentaires de la parenté. Paris: Presses Universitaires de France.

Ritz, German. 2002. Nić w labiryncie pożądania. Gender i pteć w literaturze polskiej od romantyzmu do postmodernizmu. Tłum. B. Drąg. Warszawa: Wiedza Powszechna. 